\title{
Pengaruh Pengemasan Buah Pisang Cavendish (Musa acuminata AAA Group) dalam Plastik Vakum terhadap Kondisi Fisik, Fisiologis, dan Ekspresi Gen Selama Proses Pematangan Buah
}

\author{
Anniza Nurrahmah, Fenny Martha Dwivany \&, Rizkita Rachmi Esyanti \\ Sekolah Ilmu dan Teknologi Hayati - Institut Teknologi Bandung \\ Jl. Ganesha no. 10, Bandung 40132 \\ Email: fenny@sith.itb.ac.id
}

\begin{abstract}
Abstrak. Buah pisang Cavendish merupakan salah satu komoditas buah unggulan di Indonesia dengan nilai produksi yang cukup besar. Hasil produksi kebanyakan digunakan dalam skala nasional dan hanya $10 \%$ yang dijadikan komoditas ekspor. Kendala terbesar yang menghambat proses ekspor pisang dari Indonesia adalah umur simpan pisang yang pendek. Bahan plastik polietilen telah banyak digunakan sebagai kemasan makanan karena aman digunakan. Oleh karena itu, penelitian ini bertujuan untuk mengetahui efek pengemasan buah pisang Cavendish dalam plastik vakum terhadap proses pematangan buah pisang. Buah pisang non-treated ethylene dibagi ke dalam beberapa perlakuan diantaranya, plastik vakum dan plastik vakum dan kitosan, dimana buah pisang dibersihkan dengan etanol dan disalut dengan kitosan. Analisis efek perlakuan kemudian diuji secara fisik, fisiologis, dan molekuler. Hasil pengamatan fisik menunjukkan perlakuan plastik vakum kitosan memiliki kondisi fisik paling baik selama 14 hari pengamatan dan paling disukai panelis pada uji organoleptik. Namun perlakuan ini menunjukkan nilai TSS yang lebih tinggi dibandingkan kontrol. Hasil studi ekspresi gen menunjukkan tingkat ekspresi gen MaACO1 yang menurun pada perlakuan plastik vakum dan kitosan dibandingkan dengan dua perlakuan lainnya. Kesimpulan dari penelitian ini adalah penyimpanan buah pisang dalam plastik vakum berpengaruh pada kondisi fisik, fisiologis, dan ekspresi gen pematangan MaACO1.
\end{abstract}

Kata kunci: kitosan; pematangan buah; pisang Cavendish; plastik vakum.

\section{$1 \quad$ Pendahuluan}

Buah pisang varian Cavendish (Musa acuminata AAA group) merupakan spesies buah pisang yang dapat ditemukan secara luas di Asia Tenggara. Produksi pisang di Indonesia cukup besar, menurut Nurhayati dan Novianti [1], produksi pisang Indonesia pada tahun 2013 mencapai angka 6,28 juta ton. Selain itu, Indonesia merupakan salah satu prosuden pisang terbesar di benua Asia namun sayangnya, kebanyakan produksi pisang masih dimanfaatkan untuk 
konsumsi dalam negeri dan hanya $10 \%$ dari hasil produksi pisang yang dijadikan komoditas ekspor. Nilai ekspor buah pisang yang masih rendah disebabkan karena banyak kendala yang dihadapi dalam proses pengiriman komoditas ekspor, diantaranya usia simpan pisang yang pendek, dimana buah pisang biasanya akan matang dalam jangka waktu 4-5 hari setelah induksi gas etilen dan mengalami perubahan warna menjadi kuning.

Kader [2] melaporkan bahwa, penelitian dengan modifikasi atmosfer (MA) telah banyak digunakan untuk memelihara temperatur yang optimal serta kelembaban rata-rata selama buah dalam masa transport atau masa penyimpanan. Selain itu, modifikasi atmosfer mampu mengurangi laju respirasi, kinerja etilen, serta gangguan fisik yang dapat menyebabkan luka-luka pada kulit buah. Menurut Bhande, et al. [3], temperatur, konsentrasi $\mathrm{O}_{2}, \mathrm{CO}_{2}$, dan etilen sangat berpengaruh pada kondisi buah. Oleh karena itu, pengontrolan ruang penyimpanan buah dengan temperatur dan konsentrasi $\mathrm{O}_{2}$ rendah dan konsentrasi $\mathrm{CO}_{2}$ yang sedikit lebih tinggi dapat menurunkan aktivitas enzimatik buah sehingga buah dapat mempertahankan kondisi terbaiknya selama mungkin.

Bahan plastik polietilen telah lama digunakan sebagai salah satu bahan pengemasan makanan sebab bahan polietilen aman digunakan untuk menyimpan makanan. Menurut WS Hampshire Inc. [4], bahan polietilen aman digunakan untuk menyimpan makanan karena bersifat non-toksik dan nonkorosif, sehingga sulit bereaksi dengan makanan. Selain itu bahan polietilen juga memiliki titik didih yang cukup tinggi sehingga mampu bertahan pada suhu yang panas. Selain faktor-faktor atmosferik, faktor keberadaan patogen juga dapat mempengaruhi proses pembusukan pada buah. Adapun penggunaan polisakarida seperti kitosan juga telah dilaporkan, Jianglian dan Shaoying [5], senyawa kitosan memiliki sifat anti mikroba dan anti jamur yang baik yang dapat membantu pengontrolan laju pembusukan buah. Oleh karena itu 
penelitian ini bertujuan untuk mengetahui pengaruh penyimpanan buah pisang Cavendish dalam plastik vakum disertai dengan penyalutan kitosan terhadap kondisi fisik, fisiologis, serta ekspresi gen selama proses pematangan buah.

\section{$2 \quad$ Metodologi Penelitian}

\subsection{Persiapan Buah Pisang}

Buah pisang Cavendish yang digunakan merupakan buah pisang yang berwarna hijau dan belum diinduksi oleh gas etilen (non-treated ethylene). Buah pisang dipilih dari kelompok usia panen 9, 10, dan 11 minggu. Buah pisang kemudian dikelompokkan berdasarkan warna kulit dan ukuran buah. Buah pisang kemudian dibersihkan menggunakan sabun anti bakteri.

\subsection{Modifikasi Plastik Vakum Ziploc $®$}

Plastik Ziploc yang akan digunakan harus dimodifikasi terlebih dahulu agar dapat divakum. Modifikasi dilakukan dengan menambahkan selang akuarium dan alat check valve untuk mengatur aliran udara. Plastik Ziploc dilubangi, kemudian selang akuarium dimasukkan dan check valve dipasang pada selang yang berada di luar plastik. Gambar 1 menunjukkan hasil modifikasi plastik Ziploc.

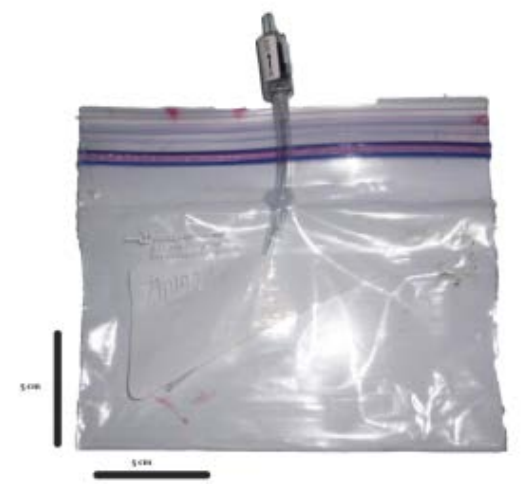

Gambar 1 Plastik Ziploc yang telah dimodifikasi 


\subsection{Pembuatan Senyawa Kitosan}

Menurut Malmiri, et al. [6], senyawa kitosan dibuat dengan mencampurkan bubuk kitosan food grade dengan asam asetat glasial. Setelah seluruh bahan tercampur, $\mathrm{pH}$ larutan kemudian disesuaikan dengan penambahan $\mathrm{NaOH}$ hingga pH mencapai 5,6.

\subsection{Skema Penelitian}

Pada penelitian ini, pisang non-treated ethylene dibagi ke dalam tiga kelompok perlakuan. Kontrol merupakan kelompok pisang yang disimpan pada suhu $25^{\circ} \mathrm{C}$ tanpa plastik, perlakuan plastik vakum merupakan kelompok pisang yang disimpan dalam plastik suhu dalam ruangan bersuhu $16^{\circ} \mathrm{C}$, sementara perlakuan plastik vakum dan kitosan merupakan kelompok buah pisang yang disalut dengan kitosan kemudian disimpan dalam plastik vakum dalam ruangan bersuhu $16^{\circ} \mathrm{C}$. Buah pisang kemudian disimpan untuk diamati kondisi fisiknya selama 7 hari. Buah pisang kemudian diinduksi pematangannya dengan menggunakan gas etilen. Setelah induksi, buah pisang diperam selama 24 jam kemudian diamati pematangannya selama 14 hari. Skema penelitian yang lebih jelas dapat dilihat pada Gambar 2.

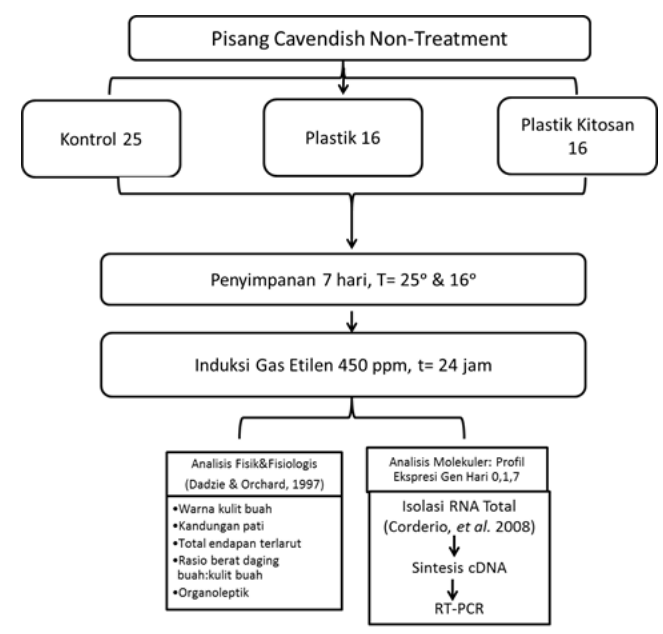


Gambar 2 Skema penelitian

\subsection{Analisis Fisik dan Fisiologis}

Setelah buah pisang diperam selama 24 jam, proses pematangannya mulai diamati. Perubahan fisik yang teramati diambil gambarnya dengan kamera CANON® IXUS HS250, sementara itu pada hari 0, 1, 4, 7 dan 14 dilakukan pengambilan sampel untuk isolasi RNA sekaligus analisis kondisi fisiologis. Metode untuk analisis fisiologis menggunakan metode Dadzie dan Orchard [7], dimana parameter yang diukur adalah uji kadar pati, berat buah, susut bobot, rasio daging:kulit buah, dan total kandungan terlarut (TSS). Pada hari ke-14 dilakukan pula pengujian secara organoleptik kepada 15 orang panelis semi terlatih dimana parameter yang diuji adalah warna, rasa, dan aroma buah pisang.

\subsection{Isolasi RNA Total Buah Pisang}

Isolasi RNA dilakukan dengan menggunakan metode Cordeiro et al. [8] yang telah dimodifikasi. Sampel yang diisolasi merupakan sampel hari ke-0, 1, dan 7. Isolasi RNA dengan metode ini membutuhkan waktu 2 hari. Setelah itu, hasil isolasi dapat dikonfirmasi secara kualitatif menggunakan metode elektroforesis dengan melalukan sampel pada gel agarosa $1,5 \%(\mathrm{w} / \mathrm{v})$ dalam buffer TAE $1 \%$, kemudian divisualisasi dibawah sinar UV. Secara kuantitatif, hasil isolasi RNA dapat dikonfirmasi menggunakan Nanodrop pada panjang gelombang $\lambda 260$ dan $\lambda 280$.

\subsection{Sintesis cDNA}

Sintesis cDNA dilakukan dengan menggunakan kit iScript ${ }^{\circledR}$ cDNA Synthesis (Biorad, No. Katalog: 170-8890). Sebelum dilakukan sintesis cDNA, sampel RNA terlebih dahulu harus dibersihkan dari kontaminan menggunakan metode DNAse (Kit DNAse I, Thermo Scientific: \#EN0521). Sampel RNA sebanyak 
1000ng dimasukkan ke dalam tabung PCR kemudian ditambahkan $1 \mu \mathrm{L}$ buffer, $1 \mu \mathrm{L}$ enzim DNAseI, dan air bebas nuklease hingga konsentrasinya mencapai $10 \mu \mathrm{L}$. Tabung PCR kemudian diinkubasi selama 30 menit dalam suhu $37^{\circ} \mathrm{C}$. Selanjutnya, ke dalam tabung dimasukkan $1 \mu \mathrm{L}$ EDTA $50 \mathrm{mM}$ dan tabung kembali diinkubasi selama 10 menit dalam suhu $65^{\circ} \mathrm{C}$. Setelah penambahan DNAse, sebanyak $11 \mu \mathrm{L}$ sampel RNA ditambahkan $1 \mu \mathrm{L}$ enzim iScript reverse transcriptase, $4 \mu \mathrm{L}$ iScript reaction mix, dan air bebas nuclease hingga volume akhir mencapai $20 \mu \mathrm{L}$. Larutan kemudian diresuspensi dan diinkubasi dalam suhu berturut-turut: $25^{\circ} \mathrm{C}$ selama 5 menit, $42^{\circ} \mathrm{C}$ selama 30 menit, dan $85^{\circ} \mathrm{C}$ selama 5 menit. Hasil sintesis cDNA kemudian dapat disimpan pada suhu $-20^{\circ} \mathrm{C}$ sebelum digunakan pada tahap selanjutnya.

\subsection{Polymerase Chain Reaction}

Pada penelitian ini telah dilakukan amplifikasi pada gen-gen yang berkaitan dengan proses pematangan pisang yaitu, MaACO dan MaACS1. Selain itu, dilakukan pula amplifikasi gen housekeeping MaActin sebagai gen referensi. Urutan primer oligonukkleotida dan besar ukuran fragmen dapat dilihat pada

Tabel 1.

Tabel 1 Urutan Primer Oligonukleotida PCR (Karmawan [9] dan Handayani [10])

\begin{tabular}{c|c|c|c}
\hline No. & Primer & Urutan Oligonukleotida (5' $\left.->\mathbf{3}^{\prime}\right)$ & \multirow{2}{*}{$\begin{array}{c}\text { Ukuran Fragmen } \\
\text { (bp) }\end{array}$} \\
\hline 1 & MA-ACS1 RT-F & CCGAGACTGGATGAAGAAGAA & \multirow{2}{*}{172} \\
\hline 2 & MA-ACS1 RT-R & GTCTGGGTCAAATCTGGCTC & \multirow{2}{*}{240} \\
\hline 3 & MA-ACO RT-F & CGAGATGCTTGCGTGAGAAATGG & \multirow{2}{*}{170} \\
\hline 4 & MA-ACO RT-R & TGCAGCAAATTCCTTCATCGC & \\
\hline 5 & MA-ACTIN RT-F & ACGTCTTGACCTTGCTGG & \multirow{2}{*}{} \\
\hline 6 & MA-ACTIN RT-R & TAGTTCTAGCAGCCTCAAGC & \\
\hline
\end{tabular}

PCR dilakukan dengan menggunakan kit GoTaq ${ }^{\circledR}$ Green Master Mic (Promega, No. Katalog: M7122) dan mesin Thermalcycler. Profil siklus PCR gen MaACO, MaACSI, dan MaActin dapat dilihat pada Gambar 3. Hasil PCR dikonfirmasi 
dengan menggunakan metode elektroforesis dengan melalukan sampel pada gel agarosa $1 \%(\mathrm{w} / \mathrm{v})$ dalam buffer TAE1\% dan divisualisasi di bawah sinar UV. Larik hasil amplifikasi MaACO, MaACS1, dan MaActin kemudian dikuantifikasi menggunakan perangkat lunak ImageJ ${ }^{\circledR}$. Normalisasi ekspresi gen MaACO, MaACS1 dilakukan terhadap gen MaActin.

\section{$3 \quad$ Hasil Penelitian dan Pembahasan}

\subsection{Kondisi Fisik Buah Pisang Selama Penyimpanan}

Buah pisang yang telah dipisahkan ke dalam tiga kelompok perlakuan kemudian disimpan dan diamati selama satu minggu. Selama masa penyimpanan, nampak perbedaan pada warna buah pisang dari ketiga kelompok perlakuan. Pisang kelompok perlakuan Kontrol 25 nampak menunjukkan perubahan warna dari hijau menjadi hijau kekuningan pada hari ke tujuh penyimpanan. Selain itu, kondisi fisik pisang pada perlakuan ini nampak memiliki luka-luka berwarna kecokelatan pada kulit buah. Pisang pada kedua kelompok perlakuan dalam plastik vakum (dengan atau tanpa kitosan) nampak memiliki kondisi fisik yang lebih baik. Gambar buah pisang selama penyimpanan dapat dilihat pada Gambar 3.

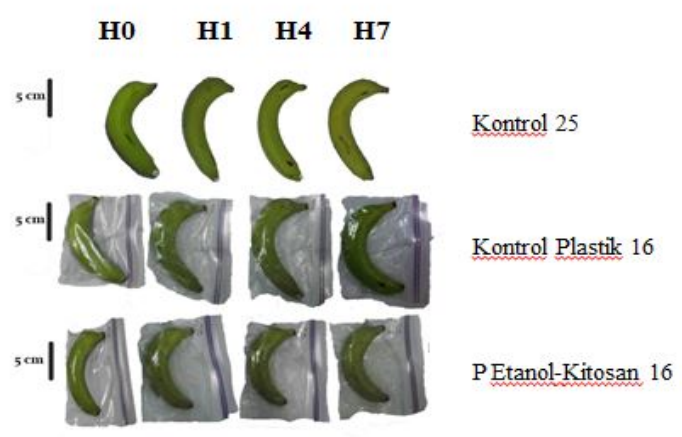

Gambar 3 Hasil Pengamatan Kondisi Fisik Buah Selama 7 Hari Penyimpanan 


\subsection{Kondisi Fisik Buah Pisang Setelah Induksi Gas Etilen}

Setelah pemberian gas Etilen dan pemeraman selama 24 jam, proses pematangan buah pisang diamati selama 14 hari. Dari hasil pengamatan tersebut, seperti yang terlihat pada Gambar 5, terdapat perbedaan kondisi fisik antara ketiga perlakuan. Pisang pada perlakuan Kontrol 25 nampak menunjukkan perubahan warna sejak dari hari ke-4 dengan menunjukkan perubahan warna kulit buah menjadi kuning. Sedangkan buah pisang pada perlakuan dalam plastik vakum (dengan dan tanpa kitosan), baru menunjukkan perubahan warna menjadi kuning dan hijau kekuningan pada hari ke-7. Berdasarkan hasil analisa kondisi fisik, perlakuan Kontrol 25 kondisi fisiknya kurang baik karena banyak luka-luka berwarna kecokelatan pada kulit sedangkan pada perlakuan plastik vakum masih memiliki kondisi fisik baik tanpa adanya luka-luka seperti yang dapat dilihat pada Gambar 4. Menurut Mohapatra, et al. [11], munculnya warna kecokelatan pada kulit pisang dapat disebabkan karena adanya kerusakan secara mekanik yang menyebabkan enzim yang mendegradasi senyawa fenol teraktivasi.

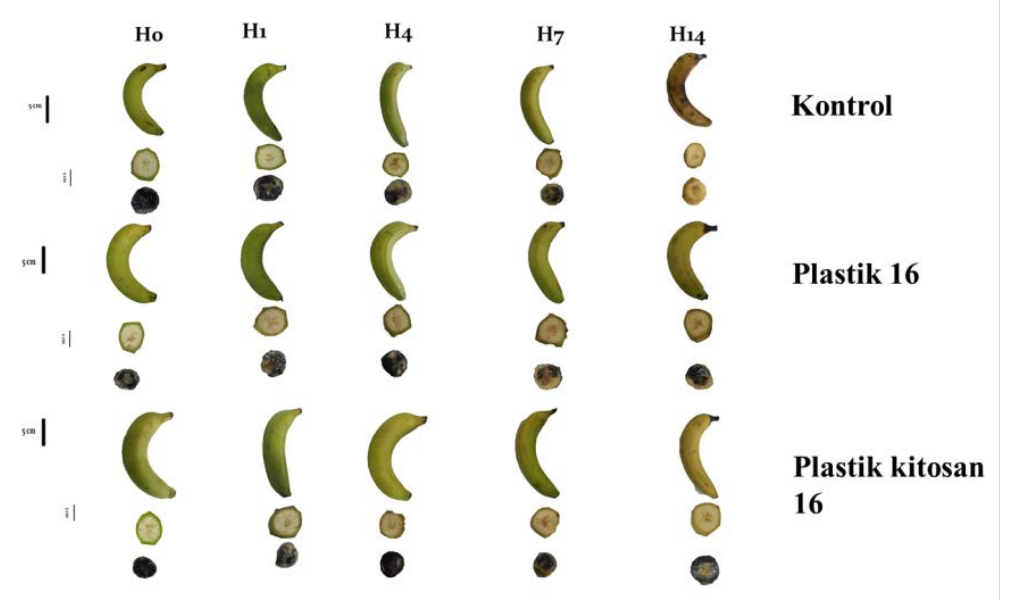

Gambar 4 Hasil Pengamatan Kondisi Buah Pisang Setelah Induksi Gas Etilen 
Selain pengamatan secara fisik, dilakukan pula uji starch-iodine. Uji tersebut dilakukan untuk melihat perubahan pati menjadi gula pada daging buah pisang. Semakin banyak gula yang terkandung dalam daging buah pisang semakin kecil area yang berubah warna menjadi biru kehitaman saat diuji dengan Iodin, seperti yang dikemukakan Dadzie dan Orchard dalam [7]. Hasil pengamatan pada Gambar 4 menunjukkan adanya perubahan area yang terwarnai pada daging buah pisang setiap hari pengamatan. Pada perlakuan dalam plastik vakum menunjukkan bahwa area daging buah yang terwarnai semakin sedikit, menandakan bahwa pati telah diubah menjadi gula sehingga area warna biru kehitaman menjadi lebih sedikit.

Hasil uji starch-Iodine menunjukkan area yang berwarna biru kehitaman dengan luas area lebih kecil pada kedua pisang kelompok perlakuan plastik vakum, sedangkan pada perlakuan Kontrol 25 menunjukkan lebih banyak area yang terwarnai. Hal tersebut menunjukkan bahwa kandungan gula pada kedua kelompok perlakuan plastik vakum lebih tinggi dibandingkan pisang perlakuan kontrol. Kandungan gula yang lebih tinggi dapat disebabkan karena pisang perlakuan vakum tetap mengalami pematangan normal, seperti yang dilaporkan Pesis, et al. [12].

\subsection{Hasil Analisis Fisiologis dan Uji Organoleptik}

Terdapat tiga parameter fisiologis yang diuji pada penelitian ini. Ketiga parameter tersebut adalah Total Kandungan Terlarut atau Total Soluble Solids (TSS), rasio daging:kulit buah, dan persentase susut bobot. Nilai Total Kandungan Terlarut merepresentasikan kadar gula yang terkandung dalam daging buah. Semakin matang buah maka nilai TSSnya akan semakin tinggi, seperti yang dikatakan Dadzie dan Orchard dalam [7].

Berdasarkan hasil pengukuran nilai Total Kandungan Terlarut yang dapat dilihat pada Gambar 5, terlihat bahwa kelompok perlakuan Plastik kitosan 16 
yang disimpan dalam plastik vakum menunjukkan peningkatan nilai TSS pada tiap hari pengamatan. Pada kedua kelompok perlakuan lainnya yaitu, Kontrol 25 dan Plastik 16 nampak menunjukkan nilai TSS yang tidak berbeda signifikan. Kemungkinan hal ini terjadi karena pada penelitian ini tidak dapat digunakan pisang yang sama karena pengukuran TSS dilakukan pada tiga pisang yang berbeda dan masing-masing pisang harus disampling pada tiap titik pengamatan yang berbeda. Selain itu terdapat perbedaan umur fisiologis pisang yang dijadikan sampel pada saat dimulai penelitian (umur 9, 10, 11 minggu saat panen). Menurut Marriott, et al. [13], tingginya nilai TSS menunjukkan proses pematangan normal. Perlakuan pisang yang disimpan dalam plastik vakum proses pematangannya berlangsung normal sehingga nilai TSSnya tidak berbeda jauh dengan kontrol.

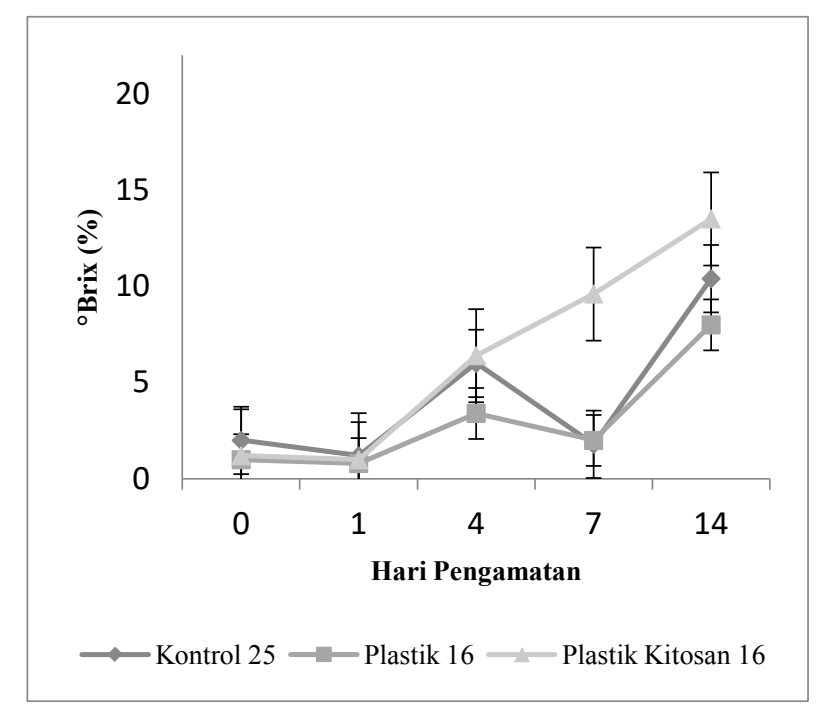

(a) 
Pengaruh Pengemasan Buah Pisang Cavendish (Musa acuminata AAA Group) dalam Plastik Vakum terhadap Kondisi Fisik, Fisiologis, dan

Ekspresi Gen Selama Proses Pematangan

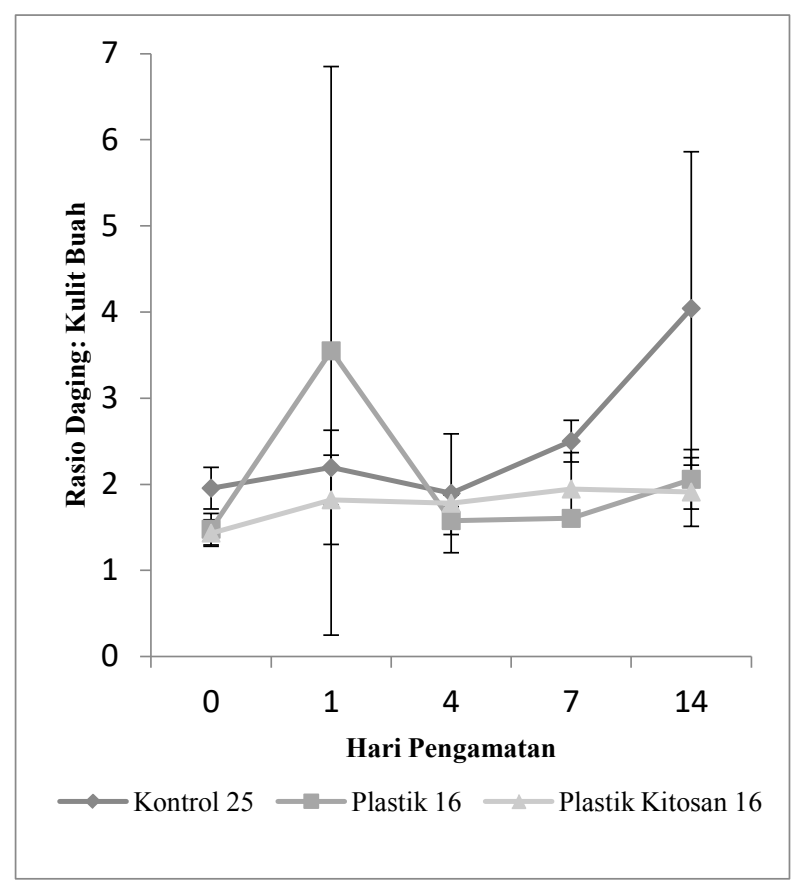

(b)

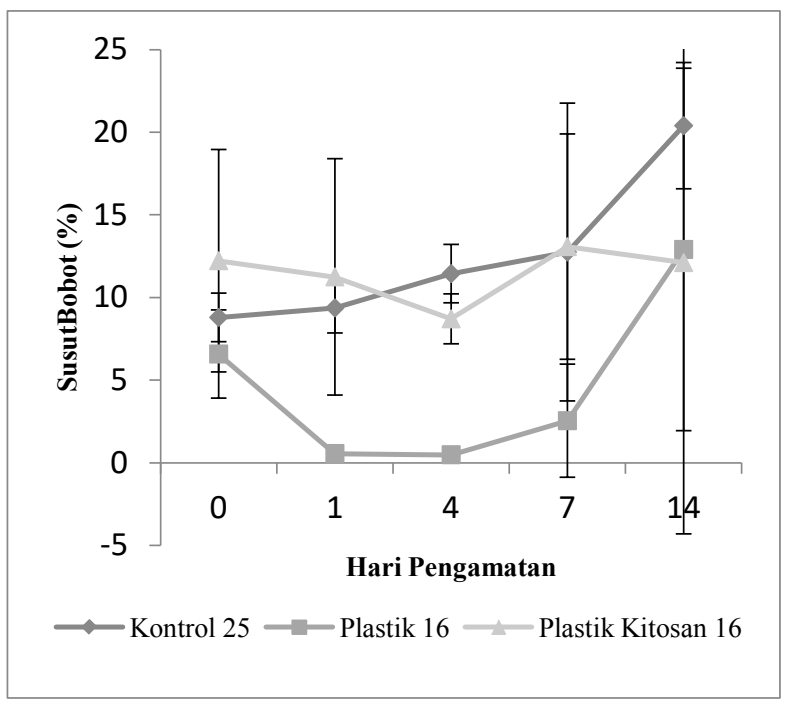

(c)

Gambar 5 Hasil Analisis Fisiologis Buah Pisang: (a) Total Kandungan Terlarut, (b)

Rasio Daging: Kulit Buah, dan (c) Susut Bobot 
Hasil pengukuran nilai rasio daging dan kulit buah dapat dilihat pada Gambar

5, nampak pada ketiga perlakuan menunjukkan pola yang meningkat, terutama pada perlakuan Kontrol 25. Pada kedua perlakuan yang disimpan dalam plastik vakum juga menunjukkan adanya peningkatan nilai rasio daging: kulit buah meskipun tingkat kenaikannya tidak signifikan. Perubahan nilai rasio daging: kulit buah dapat dijadikan parameter tingkat kematangan buah pisang karena perubahan nilai tersebut menunjukkan adanya perpindahan air akibat perubahan tekanan osmotik antara kulit dan daging buah saat kandungan gula dalam daging meningkat seiring meningkatnya pematangan, seperti yang dilaporkan Tapre dan Jain [14].

Hasil pengamatan perubahan susut bobot dapat dilihat pada Gambar 5. Berdasarkan hasil pengamatan, dapat terlihat bahwa perlakuan Kontrol 25 dan perlakuan Plastik 16 menunjukkan peningkatan perubahan susut bobot yang signifikan sejak pengamatan hari ke-0 hingga hari ke-14 meskipun persentase perubahan susut bobot perlakuan plastik vakum lebih kecil. Sementara itu, perubahan susut bobot pada kelompok perlakuan Plastik Kitosan 16 juga menunjukkan adanya perubahan, namun perubahannya tidak terlalu signifikan. Menurut Dadzie dan Orchard [7], perubahan susut bobot dipengaruhi oleh degradasi dinding sel yang terjadi selama proses pematangan juga meningkatnya permeabilitas lapisan sel terluar pada uap air. Nilai susut bobot yang lebih rendah pada perlakuan plastik vakum sesuai dengan hasil penelitian oleh Pesis, et al. [12] yang menyatakan bahwa nilai susut bobot perlakuan dalam plastik vakum lebih rendah dibandingkan perlakuan kontrol.

Uji organoleptik dilakukan pada buah pisang dari seluruh perlakuan pada hari ke-14. Uji organoleptik dilakukan oleh 15 panelis semi-terlatih yang menilai tiga parameter buah yaitu, rasa, aroma, dan warna kulit. Hasil uji organoleptik 
Pengaruh Pengemasan Buah Pisang Cavendish (Musa acuminata AAA Group) dalam Plastik Vakum terhadap Kondisi Fisik, Fisiologis, dan

Ekspresi Gen Selama Proses Pematangan

dapat dilihat pada Gambar 6. Dari hasil uji dapat dilihat bahwa berdasarkan tiga parameter yang diuji, para panelis masih lebih menyukai buah pisang pada perlakuan plastik vakum dengan kitosan dan etanol.

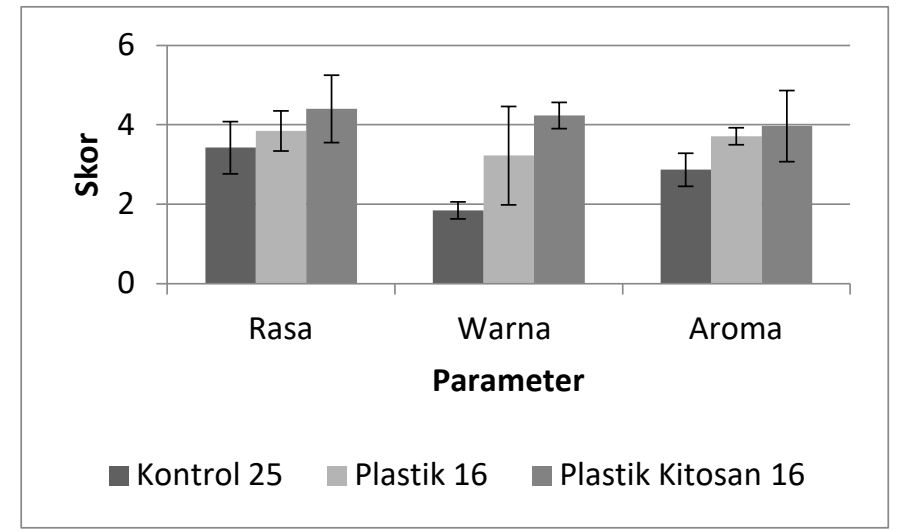

Gambar 6 Hasil Uji Organoleptik

\subsection{Hasil Analisis Molekuler}

Pengambilan data molekuler dilakukan dengan melakukan isolasi RNA total buah pisang dan sintesis cDNA. Hasil sintesis cDNA kemudian dapat digunakan sebagai template untuk amplifikasi gen-gen yang berhubungan dengan proses pematangan buah yaitu gen MaACO dan MaACS1 dan gen pembanding MaActin. Hasil amplifikasi gen dengan metode PCR dapat terlihat dari terbentuknya larik yang ukurannya sesuai dengan yang diharapkan 


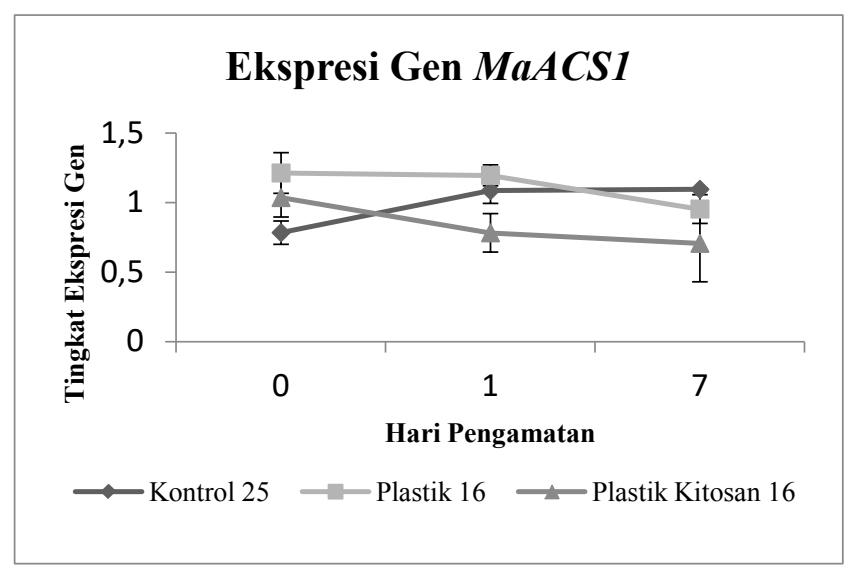

(a)

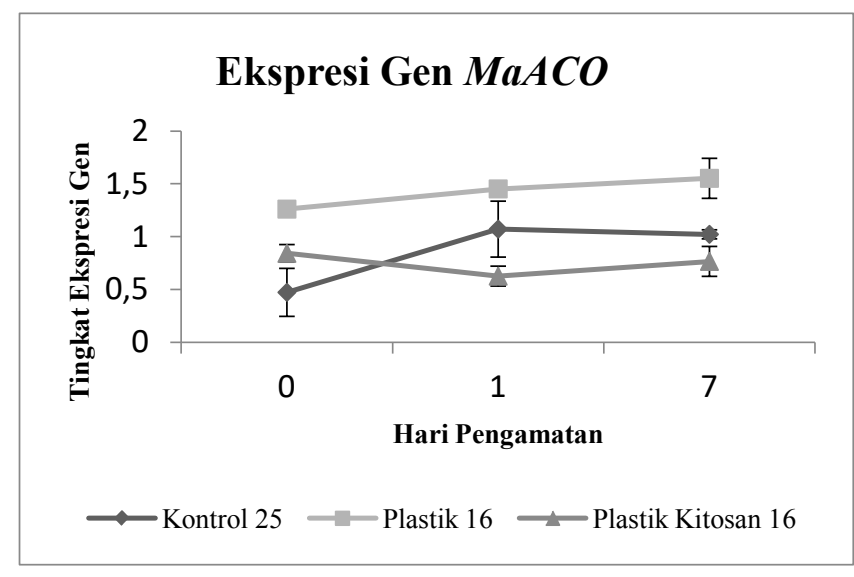

(b)

Gambar 7 Hasil Analisa Ekspresi Gen MaACS1 (a) dan MaACO (b)

Hasil PCR gen MaACO, MaACS1, dan MaActin kemudian dianalisa lebih lanjut dengan menggunakan perangkat lunak Image $\mathbb{~}{ }$. Hasil analisa menggunakan ImageJ kemudian digunakan untuk membandingkan tingkat ekspresi gen MaACO dan MaACS1 terhadap gen referensi MaActin. Hasil perbandingan seperti yang terlihat pada Gambar 7. Pada tingkat ekspresi gen MaACS1, setelah induksi oleh gas Etilen pada hari ke-0, tingkat ekspresi gen MaACS1 pada kedua perlakuan plastik vakum memiliki pola penurunan, sedangkan pada 
perlakuan kontrol 25 tingkat ekspresi gennya memiliki pola kenaikan. Hal ini mengkonfirmasi hasil analisis fisik yang menunjukkan proses pematangan yang lebih lambat daripada perlakuan kontrol. Dari hasil tersebut, diduga penurunan ekspresi gen MaACS1 dipengaruhi oleh perlakuan vakum. Hasil analisa statistik menunjukkan tidak ada perbedaan signifikan $(\mathrm{P}>0,05)$ pada tingkat ekspresi gen MaACSI antara ketiga perlakuan.

Pada ekspresi gen $M a A C O$, dapat teramati bahwa perlakuan Kontrol 25 dan Plastik 16 memiliki pola kenaikan tingkat ekspresi selama pengamatan, sementara kelompok perlakuan Plastik Kitosan 16 justru menunjukkan pola penurunan tingkat ekspresi. Gen $M a A C O$ memiliki fungsi untuk mengaktivasi kerja enzim ACC oksidase yang akan mengubah senyawa ACC menjadi etilen, seperti yang dikatakan Taiz dan Zeiger [15]. Meningkatnya tingkat ekspresi gen dapat disebabkan oleh adanya induksi etilen eksogen seperti yang dikatakan Watada [16]. Berdasarkan hasil analisa statistik, tingkat ekspresi gen perlakuan Platik Kitosan 16 memiliki beda signifikan $(\mathrm{P} \leq 0,05)$ dengan kedua perlakuan lainnya. Rendahnya tingkat ekspresi $M a A C O$ pada perlakuan ini dapat disebabkan karena tingginya konsentrasi $\mathrm{CO}_{2}$ dalam plastik vakum pada perlakuan Plastik Kitosan 16. Menurut Taiz dan Zeiger [15], tingginya konsentrasi $\mathrm{CO}_{2}$ dapat menghambat ekspresi gen $M a A C O$.

\section{Ucapan Terima Kasih}

Tim penulis ingin mengucapkan terima kasih kepada bantuan riset dari Pusat

Penelitian Biosains dan Bioteknologi ITB tahun 2016 kepada Fenny M.

Dwifany yang telah membantu kelancaran penelitian ini.

\section{$7 \quad$ Referensi}


[1] Nurhayati, Leli. Novianti, Outlook Komoditi Pisang, Pusat Data dan Informasi Sistem Pertanian, 2014.

[2] Kader, Adel A., Modified and Controlled Atmosphere Storage of Tropical Fruits, ACIAR, pp.239-249, 1994.

[3] Bhande, S.D., Ravindra, M.R., \& Goswami, T.S., Respiration rate of banana fruit under aerobic conditions at different storage temperature, Journal of Food Engineering, 87, pp. 116-123, Nov. 2008.

[4] WS Hampshire Inc., Polyethylene, WS Hampshire Inc. http://www.wshampshire.com/pdf/psg_uhmw_polyethylene.pdf, (23 Desember 2016).

[5] Jianglian, Duan \& Shaoying, Zhang, Application of Chitosan Based Coating in Fruit and Vegetable Perservation: A Review, Journal of Food Processing \& Technology, 4(5), pp. 1-4, 2013.

[6] Malmiri Jafarizadeh., Osman, A., Tan, C.P., Rahman, Abdul, Development of an adible coating based on chitosan-glycerol to delay 'Berangan' banana (Musa sapientum cv. Berangan) ripening process, International Food Research Journal, 18(3), pp. 989-997, 2011

[7] Dadzie, B.K., Orchard, J.E., Routine Post Harvest Screening of Banana/Plaintain Hybirds: Criteria and Methods, INIBAP Technical Guidelines 2, International Plant Genetic Resources Insitute, Rome, Italy, 1997.

[8] Cordeiro, M., Silva M., de Oliviera-Filho, E., de Miranda, Z., Aquino, F., Fragoso, R., Almeida, J., \& de Andrade, Leide R.M., Optimization of $A$ Method in Total RNA Extraction from Brazilian Native Plants Rich in Polyphenol and Polysaccharides, Brasilia, 2008.

[9] Karmawan, L.U., Suhandono, S. \& Dwivany, F.M. Isolation of Ma-ACS Gene Family and Expression Study of Ma-ACS1 Gene in Musa acuminate Cultivar Pisang Ambon Lumut, Journal Hayati of Bioscience, 16(1), pp. 35-39, 2009.

[10] Handayani, R. U. Studi Pola Ekspresi Keluarga Multigen MaACS dan gen MaACO pada Tahap Perkembangan Vegetatif dan Proses Pematangan Buah Pisang Amnbon (Musa sp. AAA Group) Menggunakan Metode Real Time PCR (qPCR), Tesis Magister Bioteknologi, Departemen Bioteknologi, Institut Teknologi Bandung, Bandung, 2010.

[11] Mohapatra, D., Mishra, S. \& Sutar, Namrata, Banana Post Harvest Practices: Current Statur and Future Prospect- A Review, Agricultural Reviews, 31(1), pp. 56-62, 2010.

[12] Pesis, E., Arie, R.B., Feygenberg, O. \& Fillamizar, F. Ripening of Ethylene-pretreated Bananas Is Retarded Using Modified Atmosphere and Vacuum Packaging, Horticultura Science, 40(3), pp. 726-731, 2005. 
Pengaruh Pengemasan Buah Pisang Cavendish (Musa acuminata AAA Group) dalam Plastik Vakum terhadap Kondisi Fisik, Fisiologis, dan

Ekspresi Gen Selama Proses Pematangan

[13] Marriott, J., Robinson, M., KArikari, S., Starch and Sugar Transformation During the Ripening of Plantains and Bananas, Journal Science of Food and Agriculture, 32, pp. 1021-1026, 1981.

[14] Tapre, A.R. \& Jain, R.K., Study of Advanced Maturity Stages of Banana, International Journal of Advanced Engineering Research and Studies, 1(3), pp. 272-274, 2012.

[15] Taiz, L. \& Zeiger, E. Plant Physiology, ed. 4, Sinnauer Associates, 2006.

[16] Watada, A., Effects of Ethylene on The Quality of Fruits and Vegetables, Food Technology, pp. 82-85, 1986. 